\title{
Youth Involvement in Agricultural Production in Obi Local Government Area, Nasarawa State, Nigeria
}

\author{
*A. A. Girei ${ }^{1}$, N. D. Saingbe ${ }^{1}$, S. B. Ohen ${ }^{2}$, E.A. Gimba ${ }^{1}$ \\ ${ }^{1}$ Department of Agricultural Economics and Extension, Nasarawa State University, Keffi. \\ ${ }^{2}$ Department of Agricultural Economics, University of Calabar, Calabar, Cross River State, Nigeria.
}

\begin{abstract}
This present study was focused on the assessment of youth involvement in agricultural production activities in Obi Local Government Area of Nasarawa State, Nigeria. The objectives where to; describe the socioeconomic characteristics of respondents, determine youths' perception towards agricultural production, reasons for participation in agricultural production activities and identify constraints to participation in agricultural production. The study employed simple random technique in the selection of the respondents who from two (2) secondary schools in Obi Local Government Area (LGA).In all, Fifty (50) students and fifty (50) staff were selected from $f$ the two (2) schools to give a total of one hundred 100 respondents. Descriptive statistics was employed to analyze the data. The results showed that majority (52\%) of the respondents had positive perception towards agricultural production as they perceived that agriculture does not reduce one's status in the society. Similarly, agriculture is not only practiced by school dropouts. Apart from output marketing, (1.7\%), goat rearing $(1.7 \%)$, and swine production $(1.7 \%)$, in which majority are less involved in, most of the respondents $(52.2 \%)$ were involved in crop production, and farm labour as a means of employment. It was also shown that most of the respondents (32\%) have insufficient land, lack of incentive from government and lack of infrastructure in rural areas as major constraints. The study recommended that youth's knowledge of basic farming activities through establishment of Agricultural Training Centers should be enhanced and credit facilities for youths in agriculture should be provided through micro finance and commercial banks.
\end{abstract}

Keywords-Youth, Involvement, Agricultural Production.

\section{INTRODUCTION}

Agriculture sector plays a pivotal role in the economic development of Nigeria. In spite of this, rural youth faced several challenges regarding livelihood. As a result, they often prefer to migrate to urban areas and not minding the type or quality but to take up low paying jobs.

Recently, youth restiveness in Nasarawa State has been prominent issue of communal violence and lawlessness which resulted into loss of lives and properties worth millions of Naira, Federal Government of Nigeria (FGN, 2001). It is envisaged that youth restiveness is politically, socially, and religiously motivated and has existed for a long time in most parts of the world. Young people all over the world are a vital and important segments of the society in which they live. Therefore, a disciplined, focused and low-abiding youth can create a bright future for any nation. Conversely, lawless, indulgent and violent youths are great threat to a nation's peace and security, Federal Government of Nigeria, (FGN, 2001).

The national youth development policies (FGN, 2001) defines youths as people aged between 18-35 years, and constitute about 40 million people in Nigeria. The total population of youth between 18 and 35 years in Nigeria was 45.4 million in 2006 which was 34 percent of the total population. Elegbeleye (2005) defined youth restiveness as a sustained protestation embarked upon to enforced desire outcome from a constituted authority by an organized body of youth. It is marked by violence and disruption of lawful activities. Youth restiveness is despicable act being perpetrated by a significant proportion of our youth in our various communities that cannot longer be ignored as the name implies. It is combination of any action, (Breitenbach, 2006). The situation has further led most youths into cultism, prostitution and street begging in the society.

Concepts of Youths in Agriculture 
The term youth do not have a particular definition. It is seen as the stage of human development. According to Erik, (1994), youths are regarded as a group of people between the ages of 19 to 40 years of age. Jibowo (1989) described youths as valuable assets to agricultural extension and rural development. He identified a number of characteristics of youths which when nurtured and utilized would enhance agricultural extension and rural people development which include reduced fair of failure, minimize risk aversion, faster reaction time, greater physical strength, social prosperity and innovation proneness. UNESCO (1991) opined that preparation of any nation for productive life in the rural area depends upon the policies and programmes designed for the youths.

Youths have desirable qualities that can promote agriculture; most of them have strong apathy towards it (Jibowoet al., 2005). This has resulted in mass unemployment and lack of sustainable livelihood activities among the youths (Breintenbach, 2006). The situation has further led most youths in to cultism, prostitution, street begging and restiveness behavior (Sodique, 2006). With fewer youths in to agriculture, the long-term sustainable agricultural development will be in doubt situation which will further lead to regional food import bill continuing to increase while regional agricultural production fall (Sodique, 2006). The significant increase in the price of food due to external shocks such as conflict and movement in oil price are issues of relevance. As a result, it is necessary to encourage increased food production by increasing the number of producer and the level of productivity. The youth's population is strategic to success of these efforts to boost food production.

Youth's unemployment is compounded by the fact that a large portion of the population in developing countries tend to be youth. The youths today increasingly development of negative view of agriculture as a source of employment to white collared easy lifestyle is a cause of worry (Okeowo, et al., 1999). This shift has been partly due to lack of information about the opportunities in the agricultural industry, as well as the flawed perception that most educated young people have had about framing. The prevailing misconception that pursuing agriculture would give them social status as well as provide employment opportunities for the followings;

i. Livestock production: Is a component of agriculture, concerned with raising birds and animals such as poultry, goats, sheep, pigs, rabbits, for various purposes that provide a good source of income to youths to engage in. ii. Crop production: This is another area of agriculture concerned with production of a wide range of crop including fruits, vegetables and also ornamental plants for income generation.

iii. Agribusiness: This also provides activities from input supply to production, processing, handling and marketing (Tee and Seha, 2003). Agriculture is considered to be a business as it opens up investment opportunities for generating income to individual, organization and the nation.

iv. Aquaculture: This deals with the raising of fish and other aquatic livestock. Agriculture has played an important role in human civilization in Nigeria. It plays a significant role in eradicating youth unemployment and can provide productive alternative for youths and help reduce restiveness and other social vices.

There are several advantages of youths participation in agriculture as it is generally believed that they have the latent energy requirement, capacity and capability to participate in all aspect of agricultural operations, propensity to learn and take any available advantage of new ideas, , innovations or technologies and besides, they are excellent source of ideas, innovations and source of new technologies. Agriculture is generally considered to be the main source of livelihood to not only the rural areas but to some extent the urban areas of the country and has high level of employment potentials. Despite all this positive contributions of agriculture to the daily life of any nation with Nigeria in particular, agriculture remains very unattractive to the teaming youths leading to the movement and involvements in all social vices either due to frustrations or in search of possible opportunities and better jobs.

The Nigerian agricultural sector is confronted with critical challenges, due to high rate of youth's restiveness (Nonyelu, 1997). Unfortunately, the youths who are supposed to replace them are withdrawing from farming due to lack of incentive, low productivity and economic return associated with the profession (Nwanuah, 2000). However, the drudgery and low productivity associated with farming constitutes major impediments to young people participation in the sector to reduce restiveness.

The role of rural youths in agricultural development is grossly underestimated, in view of the fact that they contribute significant development efforts which, unfortunately, are usually undervalued or unutilized along with their economic potentials. This category of youths, are unfortunately seen as national burden and in fact remain untapped rural resources (Adedoyin, 2005). Based on the 
forgoing, this research attempts to examine the involvement of youths in agricultural production in the study area

i. What are the socio-economic characteristics of youth's restiveness in agricultural production?

ii. What is the perception of the youths towards agricultural production?

iii. What are the levels of youth's involvement in agricultural production?

iv. Why do youths participate in agricultural production?

v. What are the constraints to youth's participation in agricultural production?

\section{Objective of the Study}

The specific objectives of the study are to:

i. describe socio-economic characteristics of respondents,

ii. examine the perception of youths towards agricultural production ,

iii. determine level of youths involvement in agricultural production,

iv. identify reasons for youths participation in agricultural production,

v. discuss constraints limiting youths participation in agricultural production ,

\section{METHODOLOGY}

\section{The Study Area}

The study was conducted in Obi Local Government Area in Nasarawa State, Nigeria. Obi Local Government is located in the southern part of Lafia on latitude $7^{0} 31$ North and longitude $6^{0} 31$ East. It headquarter is in the town of Obi. It has an area of $967 \mathrm{Km}^{2}$ and a population of 148,874 inhabitants (NPC, 2006). The Local Government Area is characterized by long period of rainy season (MarchOctober). The mean annual rainfall is about 1270 $1540 \mathrm{~mm}$ received over seven to eight months (April to October) of rainy season with four months of dry season and annual temperature ranging from $22.7^{\circ} \mathrm{C}$ to $36.8^{\circ} \mathrm{C}$ (Meteorological department, NSG, 2008). The major tribes are Alago, Eggon, Kanuri, Migili and Gwandara. Others include Tiv, Hausa-Fulani, Igbo, Yoruba, and Ngas. Most of the people are farmers who engage in trading and artisan work as part time commercial activities (NPC, 2006).

\section{Sampling Techniques}

Firstly, two schools; Government Secondary School and Government Science School were purposively selected from Obi Local Government Area, Nasarawa State. Secondly, fifty (50) students and staff of age ranging from (18-34) years and the mean age is 23years were randomly selected from the two (2) schools to give a total of 100 respondents for the study.

\section{Method of Data Collection}

Primary data were used for the study; the data were collected through a structured questionnaire and interview schedule administered to respondents. The instrument captured questions related to all the objectives of the study.

\section{Analytical Techniques}

Simple descriptive statistics such as frequency counts, mean and percentage was used to satisfy all the objectives.

\section{RESULTS AND DISCUSSION} Socio-economic Characteristics of Respondents

Gender: Table 1 revealed that $62 \%$ of the respondents were male while $38 \%$ were females, this implies that there are more male involved in agriculture in the study area. Chukwendu and Adekoya (1995) reported that women's lack of land ownership right has hindered long time participation in agriculture.

Marital Status: Majority (67\%) of the respondents are single while $33 \%$ are married. This shows that the respondent comprise mainly of people who probably are yet to get married and this implies that agriculture employ high percentage of youth especially in the rural area where agriculture is the major occupation of self-reliance and generation of income (Kompmann, 1999).

Educational Qualification: it was observed that $71 \%$ of the respondents are secondary school students while $28 \%$ have completed tertiary education. Only $1 \%$ has completed primary education, this implies that most of the respondents are graduates and this may have impact on their level of participation in agricultural innovation by extension agent as a way of overcoming restiveness. Ogumbameru (2004) also reported that highly educated farmer can get information on modern agricultural production techniques from a wide range of source such as extension agents, electronic or print media and internet.

Membership of cooperative: The results also indicated that $79 \%$ of the respondents do not belong to any cooperative while only $21 \%$ are member of cooperative. This may affect their level of awareness about improved practice and may also affect their ability to purchase inputs at subsidized prize.

Extension Visit: The results also revealed that majority $63 \%$ of the respondents do not have access to extension agents while only $37 \%$ has contact with extension agents, this may also affect their level of participation in agriculture as extension agents play critical role in increasing youth's adoption of new farm practices. 
Age of the respondents: The results revealed that the majority age range of the respondents is $(18$ - 34) 16 years and the mean age is 23 , going by the definition of youth as a person aged between 12 and 30 years by Vision 2010 report (2005). It also showed that $49 \%$ of the respondents are between the age ranges of (16-21) $24 \%$ are between the age range of (22-27) and $27 \%$ are between the age ranges of (28-35). This implies that in Nigeria, youth formed a very significant proportion of rural communities for which their existence and potential are well known.

Table.1: Socio-economic Characteristics of Respondents

\begin{tabular}{|c|c|c|}
\hline Characteristics & Frequency & Percentage \\
\hline \multicolumn{3}{|l|}{ Gender } \\
\hline Male & 62 & 62.0 \\
\hline Female & 38 & 38.0 \\
\hline Total & 100 & 100 \\
\hline \multicolumn{3}{|l|}{ Marital Status } \\
\hline Single & 67 & 67.0 \\
\hline Married & 33 & 33.0 \\
\hline Total & 100 & 100 \\
\hline \multicolumn{3}{|c|}{ Educational Qualification } \\
\hline Primary & 1 & 1.0 \\
\hline Secondary & 71 & 71.0 \\
\hline Tertiary & 28 & 28.0 \\
\hline Total & 100 & 100 \\
\hline \multicolumn{3}{|c|}{ Membership of cooperative } \\
\hline Yes & 21 & 21.0 \\
\hline No & 79 & 79.0 \\
\hline Total & 100 & 100 \\
\hline \multicolumn{3}{|l|}{ Extension Visit } \\
\hline Yes & 37 & 37.0 \\
\hline No & 63 & 63.0 \\
\hline Total & 100 & 100 \\
\hline \multicolumn{3}{|c|}{ Age of respondents } \\
\hline $16-21$ & 49 & 49.0 \\
\hline $22-27$ & 24 & 24.0 \\
\hline $28-35$ & 27 & 27.0 \\
\hline Total & 100 & 100 \\
\hline Mean Age 23 & & \\
\hline
\end{tabular}

Source: Field survey, 2015

Perception of Youths towards Agricultural production The results as presented in Table 2 revealed that $44 \%$ of the respondents disagree that farming is for school dropout while $21 \%$ are of the opinion that farming is for school dropout. This implies that majority of the respondents have positive disposition towards farming as a way of employment/profession. The results also showed that $45 \%$ of the respondents do not believed that farming reduces one's status in the society. This means that youth perceive agriculture as a main stay of their economy and as an art of pride. It was also revealed by $52 \%$ of the respondents that farming is not for the less privileged. Only $12 \%$ believed that farming is practiced by the less privileged. The mentality of an individual towards any profession may seriously affect the level of adoption given to such profession. It also implies that farming is also practiced by people that are highly placed in the society, even the youths. The results revealed that $38 \%$ disagree that farming is stressful. This perception of drudgery about farming strongly affects their participation in agriculture. The results showed that $47 \%$ disagree that farming generates low income while $14 \%$ believed that farming is meant for low income earners. This explains that youth's participation in agriculture is very high in the study area as much believed that one can generate high income through farming. It was showed that $48 \%$ disagree that farming is for the aged while $14 \%$ believed that it is meant for the aged. This implies that 
youth's participation in agriculture in the study area is very

high.

Table.2: Perception of Youths towards Agricultural production

\begin{tabular}{|c|c|c|}
\hline Characteristics & Frequency & Percentage \\
\hline \multicolumn{3}{|c|}{ Farming is for school dropout } \\
\hline Strongly agree & 21 & 21.0 \\
\hline Agreed & 14 & 14.0 \\
\hline No opinion & 6 & 6.0 \\
\hline Disagree & 44 & 44.0 \\
\hline Strongly disagree & 15 & 15.0 \\
\hline Total & 100 & 100 \\
\hline \multicolumn{3}{|c|}{ Farming reduces one's status in the society } \\
\hline Strongly agree & 21 & 21.0 \\
\hline Agreed & 15 & 15.0 \\
\hline No opinion & 5 & 5.0 \\
\hline Disagree & 45 & 45.0 \\
\hline Strongly disagree & 14 & 14.0 \\
\hline Total & 100 & 100 \\
\hline \multicolumn{3}{|c|}{ Farming is for the less privileged } \\
\hline Strongly agree & 12 & 12.0 \\
\hline Agreed & 13 & 13.0 \\
\hline No opinion & 8 & 8.0 \\
\hline Disagree & 52 & 52.0 \\
\hline Strongly disagree & 15 & 15.0 \\
\hline Total & 100 & 100 \\
\hline \multicolumn{3}{|c|}{ Farming is stressful } \\
\hline Strongly agree & 23 & 23.0 \\
\hline Agreed & 38 & 38.0 \\
\hline No opinion & 3 & 3.0 \\
\hline Disagree & 31 & 31.0 \\
\hline Strongly disagree & 5 & 5.0 \\
\hline Total & 100 & 100 \\
\hline \multicolumn{3}{|c|}{ Farming generates low income } \\
\hline Strongly agree & 14 & 14.0 \\
\hline Agreed & 15 & 15.0 \\
\hline No opinion & 4 & 4.0 \\
\hline Disagree & 47 & 47.0 \\
\hline Strongly disagree & 20 & 20.0 \\
\hline Total & 100 & 100 \\
\hline \multicolumn{3}{|c|}{ Farming is meant for the aged } \\
\hline Strongly agree & 14 & 14.0 \\
\hline Agreed & 15 & 15.0 \\
\hline
\end{tabular}




$\begin{array}{llr}\text { No opinion } & 6 & 6.0 \\ \text { Disagree } & 48 & 48.0 \\ \text { Strongly disagree } & 17 & 17.0 \\ \text { Total } & \mathbf{1 0 0} & \mathbf{1 0 0}\end{array}$

Source: Field Survey, 2015

\section{Level of Youth Involvement in Various Agricultural production}

Table 3 shows that $52.2 \%$ of the respondents are involved in crop production, $16.0 \%$ are involved in farm labour, $7.0 \%$ are involved in agro-processing and fish production. $1.7 \%$ is involved in output marketing, poultry production and goat rearing. None is involved in bee keeping. This revealed that majority of the youths in the study area are actively involved in crop production as their major occupation, but their participation in other aspect of agricultural ventures needs to be encouraged.

Table.3: Level of Youth Involvement in Agriculture

\begin{tabular}{lll}
\hline Activities & Frequency & Percentage \\
\hline Crop production & 60 & 52.2 \\
Farm labour & 19 & 16.6 \\
Agro-processing & 8 & 7.0 \\
Input marketing & 4 & 3.5 \\
Output marketing & 2 & 1.7 \\
Sheep rearing & 5 & 4.3 \\
Fish production & 5 & 4.3 \\
Poultry production & 8 & 7.0 \\
Goat rearing & 2 & 1.7 \\
Swine production & 2 & 1.7 \\
Bee keeping & 0 & 0 \\
Total & $\mathbf{1 1 5 *}$ & $\mathbf{1 0 0}$ \\
\hline
\end{tabular}

Source: Field survey, 2015 *Multiple responses

Reasons for Youth participation in Agricultural production

The results as presented in Table 4 revealed that $51 \%$ of the youths are actively involved in agriculture as a means of creating job for themselves in order to reduce restiveness while $18 \%$ believed it is a means of reducing poverty among them. Only $4 \%$ are of the opinion that it is a means of acquiring credit from various sources of credit facilities. This implies that the youths in the study area are involved in agriculture for job security to reduce restiveness among youths. This has strong impact in the economy as it will help reduce the level youth unemployment.

Table.4: Reasons for Youth participation in Agricultural production

\begin{tabular}{|c|c|c|}
\hline Reasons & Frequency & Percentage \\
\hline Food security & 10 & 10.0 \\
\hline Self-employment & 51 & 51.0 \\
\hline Credit acquisition opportunity & 4 & 4.0 \\
\hline Poverty reduction & 18 & 18.0 \\
\hline $\begin{array}{l}\text { Absence of desirable job } \\
\text { opportunity }\end{array}$ & 8 & 8.0 \\
\hline $\begin{array}{l}\text { To create employment for } \\
\text { other individuals }\end{array}$ & 9 & 9.0 \\
\hline Total & 100 & 100 \\
\hline
\end{tabular}

\begin{tabular}{lrl}
\hline \multicolumn{3}{c}{ Source: Field Survey, 2015} \\
Constraints Limiting Youth & Participation in \\
Agricultural production & &
\end{tabular}

The results presented in Table 5 showed that $32 \%$ of the respondents have insufficient land as their major constraints in participating actively in agriculture, 14\% see lack of initial capital to purchase inputs as their major constraints and $13 \%$ see lack of infrastructure in rural areas and inadequate training from extension as their major constraints. Only $1 \%$ sees their major constraints to be poor return to investment.

Table.5: Constraints Limiting Youths Participation in Agricultural production

\begin{tabular}{lll}
\hline Constraints & Frequency & Percentage \\
\hline Lack of incentives from government & 15 & 15.0 \\
Insufficient land & 32 & 32.0 \\
Lack of initial capital & 14 & 14.0 \\
Lack of infrastructure in rural areas & 13 & 13.0 \\
Poor return to investment & 1 & 1.0 \\
\hline
\end{tabular}




$\begin{array}{llr}\text { Labour intensive } & 9 & 9.0 \\ \text { Inadequate training from extension agents } & 13 & 13.0 \\ \text { People perception of farmers } & 3 & 3.0 \\ \text { Total } & 100 & 100\end{array}$

Source; Field Survey, 2015

\section{CONCLUSION AND RECOMMENDATIONS}

Based on the findings of this study, there is convincing rationale to conclude that much still needs to be done to enhance youth's active participation in agricultural production to overcome restiveness. This study has identified inadequate credit facilities, low returns to agricultural investments, lack of access to tractors and other farming inputs as the major impediments. Other factors perceived as constraints by respondents include public perception of farmers, lack of basic knowledge of modern farming techniques. All these problem areas must be looked into in order to encourage greater participation of youths in agricultural production to reduce restiveness among youths in Nigeria.

\section{Recommendations}

Based on the findings; the study recommends the following as policy implications:

i. Enhancements of youth's knowledge of basic farming activities through establishment of Agricultural Training Centers and strengthening of existing ones. Also, Agricultural Science and entrepreneurship scheme should be made compulsory among secondary school students to boost knowledge of agriculture among youths.

ii. Provision of credit facilities for youths in agriculture through establishment of micro-finance youth credit scheme that is affordable and easily accessible.

\section{REFERENCES}

[1] Adedoyin, S. F. and Jibowo, A. A. (2005). Youth and children programmes in Nigeria. In: Agricultural Extension in Nigeria.AESON, 251. Available at http://www.realifyofaid.org/roareport.php?tab $=$ roa200 6id=6 (Accessed $21^{\text {st }}$ May, 2013).

[2] Breitenback, M. C. (2006). A Model for Rural Youth Participation in Local Government.A South African Case Study.Annals of Social Science, 1(1): 72-84.

[3] Chukwendu, M.O and Adekoya, S. (1995). Youth participation in rural development. A case study of skeletal youth programme in Lagelu Local Government Area of Oyo State, Nigeria. In sustainable children-in-agricultural programme in Nigeria, CIP 2000.Enugu book of proceeding. Pp. 254-259.

[4] Elegbeleye, O. S. (2005). Recreational Facilities in Schools.A Panacea for Youth Restiveness.Journal of Human Ecology.18(2): 93-98

[5] Erik, E. (1994). Stages of Human Development "the theoretical basis for life model research and resource on human development, New York International Universities Press.Also available on www.lifemodel.org/.39pp.

[6] Federal Government of Nigeria (2001).National Youth Development Policy.Available at http://www.thepresidencygoza/docs/policy/Nationalyo uth-policypdf (Accessed on 1st March, 2013).

[7] Jibowo, A.A. (1998). Rural Youths: A Vital but Untapped Human Resources. Proceedings of the NAERLS (National Agricultural Extension and Research Liason Services) National Rural Youths Workshop. An Invited Paper, June 6-8, 17-49.

[8] Kompmann, M. (1999). Sector programmes and how it can contribute to poverty reduction and gender equality. Agricultural and rural development 6(2): 8-9.

[9] Meteorological Department, NSU, (2008).

[10]National Population Commission (2006).Census Result.http://www.population.gov.ng/index.php.

[11] Nigeria Vision 2010 Report (2005) National Vision 2010 Report

[12] Nonyelu, C.N. (1997). Extension for women and youths. Proceedings of the $3^{\text {rd }}$ national conference of agricultural extension society of Nigeria (AESSON) P. 80

[13] Nwanuah, C.C. (2000). Information brochure of agricultural project and extension service of the shell petroleum development co-operation of Nigeria. P.18

[14] Ogunbameru, B.O. (2014). Role on support of rural youth's programmes and sustainable development.F.A.O., Rome 27-64pp. in sustainable children-in-agriculture.June 6-8, 269-275pp.

[15] Okeowo, T.A.A., Agunbiade, J.B. and Odeyemi, L.A. (1999). An Assessment of the Level of Involvement of Farm Children in Farming Decision in Ikorodu Area of Lagos State "In farm children and Agricultural 
Productivity in $21^{\text {st }}$ Century. Proceeding of the Second

Annual Conference of Children in Agricultural Programme (CIAP) Held at the Conference Centre D.A.U., Ile-ife, May, 1999, 275-282.

[16] Sodique, F.R. (2006). "Bee-honey production: A strategy for poverty alleviation among youths in Nigeria". Annals of child youths studies 1(1):113$124 p p$.

[17] Tee, E.E and Seha, P. (2003).Youth Unemployment and Implication for Stability of Democracy in Nigeria.Department of Sociology University of Ibadan, Ibadan, Nigeria.

[18] United Nations Educational Science and Cultural Organization (UNESCO) (1991). Youth in the 1980, prepared on the occasion of the international youths, year Paris UNESCO press, in sustainable children-inagriculture, June 6-8, Pp. 269-275. 